\title{
CREATIVE PROCESS IN FICTION WRITING OF THREE INDONESIAN WRITERS
}

\author{
Iin Nuraeni \\ Department of English Education, University of Kuningan, Indonesia \\ Email: ms.iinnuraeni@gmail.com \\ Fahrus Zaman Fadhly \\ Department of English Education, University of Kuningan, Indonesia \\ Email: fahruszf@gmail.com
}

APA Citation: Nuraeni, I., \& Fadhly, F. Z. (2016). Creative process in fiction writing of three Indonesian writers. Indonesian EFL Journal, 2(2), 117-126

Received: 24-05-2016

Accepted: 26-06-2016

Published: 01-07-2016

Abstract: This research investigates the creative process in fiction writing employed by three writers of different writing genres: short story, novel, and poem. This study applied a qualitative method that involved one male and two female writers in Kuningan and Majalengka. The data collected from document analysis, observation, and interview were analyzed through descriptive qualitative method. The results of the analysis revealed that there were five creative processes of writing fiction used by the writers in writing fiction, namely preparation, incubation, insight, evaluation, and elaboration. Besides, it also revealed that novel writer is more creative than short story and poem writers since he uses all steps of creative process. In addition, the researcher found that there were some ways of exploring imagination in writing fiction, including drawing and deepen characters in the film or theater, making mind mapping to write, developing a shorter text, and expecting that the writing will be read by younger generation.

Keywords: creative process, writing fiction, fiction writers, imagination process

\section{INTRODUCTION}

Writing is a complex activity.

Therefore, the writers will need processes of thinking in order to transfer ideas, select interest topic, and arrange words into a product of writing (Kane, 2000). In addition, Huy (2015, p. 54) mentions that "writing is a complex metacognitive activity that draws on an individual's knowledge, basic skill, strategies, and ability to coordinate multiple processes." In this case, the writers should have skills of producing text, the knowledge about writing, process of energizing and motivating participants to write with enthusiasm and act through strategies to archive writing goals. The all process of writing is generally from the process of creative writing or from specific creative process (Kaufman \& Kaufman, 2009).

Creative process focuses on the processes of generating ideas and idea evaluation to get the high imagination (Kaufman \& Kaufman, 2009). The creativity in writing not only includes good idea, but also the writers' ability in all process of writing until becoming a writing product. Reisman (2013, p. 11) says that "creativity is the ability to come up with a new idea, process, or product." The ability to come up the idea usually emerge from the unconscious mind, when it comes to creative writing, many people believe that writers have special talent to conduct the all process in writing (Kaufman \& Kaufman). 
Thus, it seemed important to distinguish the process of writing, in general, from the process of creative writing, in particular. The first model of creative process comes from (Wallas, 1926) as cited in (Pope, 2005) who formalized the four-stage models of the creative process involves preparation, incubation, illumination, and verification. Therefore, different perspective comes from Csikszentmihalyi (1996) who declared that there are five creative processes in writing, namely preparation, incubation, illumination, evaluation, and elaboration. After the writer prepares to arouse curiosity about something, there are four main conditions that are important during this stage. First, the writer should pay attention to develop their work. Second, the writer should pay attention to one's goals whether their work appropriate with their plan or not. Third, the writer should keep condition in relation to the domain knowledge such as to use effective techniques in writing supported by the appropriate theory. Finally, it is important to listen to colleagues in the field to get a sense that things are moving in the right direction (Csikszentmihalyi, 1996). In this point, the writer's skill should adapt to different condition and manage their writing with whatever is needed to reach their goals. All creative process in writing requires a creative writer.

Creative writers often started with a small words or images and worked through elaboration and revision to achieve a larger idea (Kaufman \& Kaufman, 2009). The creative process certainly needed in writing, because without it, the writing would not have a progress. Therefore, to be a creative writer is not easy. It is something to do with heart, soul and the mind behind the words, because creative writing is the process of inventing or presenting our thoughts, feelings, and emotions to convey information in an appealing way. Weldon (2013) claims that "creativity cannot be taught. Not if you define creativity as the urge to make something out of nothing." On the other hand, Morley (2007) states that creative writing can be taught most effectively when students have some talent. If a teacher can shape the talent, and the students enjoy the shaping, creative writing will be taught as a craft. But, basically, creativity cannot be taught to all people because the creativity comes from people's special talent. However the talent of writing is not owned by everyone, but with capacity of knowledge, the creativity can be taught. Thus, the talent plays an important role in writing fiction.

One kind of genres in writing is fiction. According to Milhorn (2006, p. 1), "fiction is literary work whose content is produced by imagination and is not necessarily on fact." Morlay (2007) mentions some kind of fiction such as novel, short story, and flash fiction. In writing a fiction, the writers should explore the imagination to support their fiction writing, which is "imagination is frequently associated with creativityindeed, in one of its uses, imaginative is a near-synonym for creative" (Gaut, 2010, p. 1042). Therefore, someone who is imaginative would be someone who is good at conjuring up images, such as think up new possibilities, offer fresh perspectives on what is familiar, make fruitful connections between disparate ideas, elaborate original ways of seeing or doing things, project themselves into unusual situations, and so on (Beaney, 2005). In short, someone who is imaginative is someone who is creative.

From the explanations above, we can see some different perspectives of componential model of creativity. This presents study focuses on analyzing the creative process in fiction writing used by three writers. It is limited in writing 
short story, novel and poem. To analyze the creative process in writing fiction, the researcher uses Csikszentmihalyi (1996) theory about five steps on creative process including preparation, incubation, insight, evaluation, and elaboration.

Based on the background above, the problems of this research are formulated into to research questions as follows: "In terms of the process of creativity, what steps of creative process used by writers in writing fiction?" and "what are the ways of exploring imagination to write fiction writing?" Thus, the objectives of this research are to find out the difference creative process used in writing short story, novel and poem, and to find out ways of exploring imagination in writing fiction.

\section{METHOD}

This research used qualitative case study. According to Gay, Mills and Airasian (2012, p. 443), "case study is a qualitative research approach in which researchers focus on a phenomenon, such as a situation or event of study known as a bounded system." The main objective of this research is to describe the creative processes in fiction writing, especially in novel, short story, and poem. This case study allowed the researcher to obtain data by using indepth interview technique. This case study was conducted in Kuningan and Majealengka Regency of West Java Provinces by interviewing three fiction writers in Indonesia. The research was held in three phases including collecting written fiction product (document), observation, and interview. Documents were collected to identify creative process used by the writers. After reading the document, the researcher observed and interviewed the three fiction writers relating to the document. Interview session were conducted seven times in different days.
All collected data were then analyzed through qualitative procedures. The steps of data analysis involves analyzing written fiction product (documents), transcribing the interview sessions from audiotape recording, reading the transcription and translating it to English, analyzing the answer given from the interview, describing the result of the analysis, and drawing conclusion.

\section{RESULTS AND DISCUSSION}

From the data analysis, the researcher found that the three fiction writers, writer \#1 (NS) as short story writer, writer \#2 (PH) as novel writer, and writer \#3 (IRZ) as poem writer, used different steps on creative process in different genres, namely preparation, incubation, insight, evaluation, and elaboration.

\section{Steps on Creative Process in Writing Short Story}

The first writer is a female fiction writer (NS) from Kuningan. The researcher collected her nine short stories and a novel. Her short stories are: Nasehat Emak, Oktober Hitam, Takdir Sang Rembulan, Tiga Butir Pengkhianatan, Perang Takkan Pernah Usai, Negeri yang Tak Pernah Merdeka, Bisik-Bisik Sabit, Jendela yang Selalu Terbuka, and Cerita Aki Iyus, while the novel is entitled Kuningan City 2112 FAITH.

After reading all documents, the researcher conducted observation and interview. Those processes were held in three times. As result, it could be seen that writer \#1 (NS) had hobbies that influence her creative process in writing fiction. Her hobbies were watching Korean drama and drawing. There are 49 Korean drama in her notebook. From some Korean drama, there are four favorite Korean drama, namely The Great Queen of Seondeok, Good Doctor, Entertainer and Mandate of Heaven. 
Watching the drama can indirectly give inspiration to the writer to write. One of inspiration comes from "The Great Queen Seondeok" Korean drama. The drama gives inspiration to write a short story entitled "Takdir Sang Rembulan." Besides, her drawing hobby is used to create a cover book and make some cartoon characters. Dori is one of her favorite cartoon character. She was imagining that Dori is a character comes from other dimension and lives in Doburi Kingdom. Meanwhile, Dori had task to make everyone happy. From her hobby, she can explore her imagination in writing.

Furthermore, she had some personal notes or books to make a draft or outline of stories. In personal notes, there are always Dori character in many version and the book is made more colorful with stickers. Besides, she had many collection of books in her bedroom which seems like library. One of her favorite book is "De Wist" by Afifah Afra and "Sebuah Janji" by Sinta Yudisia. She imitates the writing style of her favorite writers. She elaborated stories become a novella entitled "Flower Knight" through social media, wattpad. In novella, there were chapter to chapter. The novella had five chapters and twelve sub chapters. The first chapter was published on May 19th 2016. She always posts her writing chapter to chapter through wattpad.

In observing, the researcher chooses one short story entitled "Takdir Sang Rembulan" to know the creative process in writing short story. The reason in choosing this story is because it has interesting conflict about a tradition of society. Table 1 illustrates the creative process in writing short story experienced by Writer \#1.

Table 1. List of creative processes in writing short story applied by Writer \#1 (NS)

\begin{tabular}{|c|c|c|c|l|}
\hline No & $\begin{array}{c}\text { Steps of the } \\
\text { Creative Process }\end{array}$ & Yes & No & \multicolumn{1}{|c|}{ Writer's Activities } \\
\hline 1. & Preparation & $\checkmark$ & & Written two until three stories \\
\hline 2. & Incubation & $\checkmark$ & & Writing process that is inspired by local story \\
\hline 3. & Insight & $\checkmark$ & & $\begin{array}{l}\text { Change the concept of Tauhid become Tradition of } \\
\text { societies }\end{array}$ \\
\hline 4. & Evaluation & $\checkmark$ & & $\begin{array}{l}\text { Limitation or not tell the history of the main } \\
\text { character because the text must be shorter }\end{array}$ \\
\hline 5. & Elaboration & $\checkmark$ & $\begin{array}{l}\text { Previously, the writer plans to make a long version } \\
\text { of the story in novella but it was not yet realized } \\
\text { until now }\end{array}$ \\
\hline
\end{tabular}

The results shown in the table above were gained from document analysis. Whereas, the results from the interview session were presented as follows:

The first process done was preparation. At this stage, the writer made some short stories to distinguish one story from another and to choose the good story.

Awalnya cerita ini dibuat untuk tugas mata kuliah apresiasi prosa fiksi. Kalau ada tugas bikinnya tidak hanya satu, ada sekitar dua atau tiga, tapi diambil yang paling bagus.
(Initially, the story was made to fulfill the assignment of prose fiction course. I do not write only one story but two or three stories, then I chose the best story to be submitted)

The second process done by Writer \#1 (NS) was incubation. In this process, the writer developed the stories got from society regarding the tradition, by delivering the message contained in the societies i.e. about the belief of animism and dynamism.

Takdir Sang Rembulan terinspirasi dari kisah lokal. Kadang masyarakat kita masih terikat dengan adatyang sudah jelas syirik tapi masih 
dilakukan. Jadi cerita ini dibuat untuk merubah pola pikir masyarakat yang masih menganut paham animisme dan dinamisme.

("Takdir Sang Rembulan" was inspired from local story. Sometimes, our society still believes on the tradition outside our religion. Thus, this story was written to change their thinking concept which still in area of animism and dynamism)

In creative process, the writer gave new insight. In this process, the writer got new idea to develop and change the initial concept into new concept to complete solution of the problem.

\section{Awalnya saya ingin membuat konsep tentang Tauhid yang kental, namun saya tidak tahu kenapa malah menjadi cerita tentang sebuah tradisi masyarakat. (Initially, I want to write about the concept of Tauhid but it finlly flows into traditional society story)}

Next, in evaluation process, the writer evaluates the story by deciding which part of story that should be told and not, because the text should be shorter in a short story. Thus, the writer evaluates some parts of story.

\section{Pada awal cerita memang tidak diceritakan bahwa Sekar Ayu adalah gadis yang tidak menganut agama Islam. Dia menganggap bahwa paham animisme dan dinamisme itu percaya terhadap Tuhan tapi dia tidak tau bahwa Tuhan itu Allah. Ada istilah pasrahkan kepada yang di atas, jadi dia mengambarkan tingginya Tuhan sama dengan rembulan, maka dari itu disebut Takdir Sang Rembulan itu adalah takdir dari Sang Pencipta. \\ (In the beginning of the story, it was not described that Sekar Ayu is not a Moslem. She considers that animism and dynamism believe in God but she did not know that God is Allah. There is a terminology about Pasrahkan kepada yang diatas, so she describes God as tall as moon. Thus, "Takdir Sang Rembulan" means the creator's fate.)}

The last creative process is elaboration. In this process, the writer did not elaborate the story. Previously, the writer plans to make a long version of the story but it was not yet realized until now.
Tadinya saya mau bikin versi panjang menjadi novella dari cerita ini. Jadi ada karakter protagonis dan antagonis. Suranantaka adalah karaker protagonis yang dibuat untuk mengingatkan tokoh antagonis (orang melakukan pesugihan) supaya tidak terikat adat yang tidak benar tersebut.

(Initially, I want to make long version of the story in novella. So, there are two character namely protagonist and antagonist. Suranantaka is the protagonist character who will remind the antagonist character about the "wrong" tradition)

Based on the result above, Writer \#1 (NS) only applied four steps of creative process. It could be seen that the creative process of writing a short story starts from preparation until evaluation, the writer did not do elaboration process. The elaboration process will be used by writer, if the writer will make a long version story. The writer will use elaboration process only if she intends to write a novella.

\section{Steps on Creative Process in Writing Novel}

The second writer is male fiction writer (PH) from Kuningan. The interview towards Writer \#2 was held in two times. Here, the researcher collected a novel, short story, and poem created by him. The title of the novel is Sebuah Wilayah yang tidak ada di Google Earth (2015). The title of the short story is Kurusetra (1998) and the poem is Isyarat Bunga Api (1997).

From the three kinds of fiction above, the researcher took a novel entitled Sebuah Wilayah yang tidak ada di Google Earth (2015) to know the creative process in writing a novel. Fiction writer will not write in a bad mood; when he was writing and then he felt bad, he stopped writing and does another activity. He preferred writing in calm condition and alone, when his family was sleep and there is no one disturbs him. Lately, he only writes a novel because novel needs more 
Iin Nuraeni \& Fahrus Zaman Fadhly

Creative Process in Fiction Writing of Three Indonesian Writers

challenging imagination process than writing other kind of fiction. In his perspective, writing is not used as a routine in everyday life but only as a hobby to know his character through writing. The result of interview towards Writer \#2 is shown in table 2 illustrating the creative process in writing novel.

Table 2. List of creative processes in writing novel applied by Writer \#2 (PH)

\begin{tabular}{|c|c|c|c|l|}
\hline No & $\begin{array}{c}\text { Steps on the } \\
\text { Creative } \\
\text { Process }\end{array}$ & Yes & No & \multicolumn{1}{|c|}{ Writer' Activities } \\
\hline 1. & Preparation & $\checkmark$ & & Just rewrite from writer's experienced \\
\hline 2. & Incubation & $\checkmark$ & & $\begin{array}{l}\text { Writing process when meet with some } \\
\text { people on 2012 until 2015. }\end{array}$ \\
\hline 3. & Insight & $\checkmark$ & & $\begin{array}{l}\text { New inspiration always comes based on } \\
\text { writer's experience and rewrites each } \\
\text { event. }\end{array}$ \\
\hline 4. & Evaluation & $\checkmark$ & & Editing the whole of the novel. \\
\hline 5. & Elaboration & $\checkmark$ & & $\begin{array}{l}\text { The themes is elaborated from chapter to } \\
\text { chapter of the novel }\end{array}$ \\
\hline
\end{tabular}

The results shown in the table above were gained from document analysis. Whereas, the results from the interview session were presented as follows:

The creative process of preparation stage usually becomes the interesting one to write because it arouses curiosity about something. Thus, the writer writes about what have been seen based on his experiences.

Kalau saya menuliskan apapun yang saya alami.

(I write everything I have experienced)

The second stage is incubation process. The process will be used when the writer gets inspiration. The inspiration will change and develop in order to strengthen the characters. Writer \#2 (PH) wrote this novel from 2012 until 2015. The process was longer because the writer just wrote due to his experience. The incubation process was also used to develop the character and event of the story.

Iya, saya biarkan dulu di dalam otak tidak langsung saya tulis karena nanti akan muncul sendiri. Jadi seperti hukum seleksi alam, inspirasi yang kuat akan mengalahkan yang lainnya dan memaksa saya untuk menulis, terkadang, dalam situasi apapun.

(I let the ideas stay in my mind, I did not directly write it because it will appear consciously. It is like a natural selection where the strongest inspiration will hit the others and brings me to write, sometimes, in any situation)

The third stage is insight process. After the writer developed the inspiration in incubation process, the new inspiration will emerge to continue the story in insight process. The writer used this process through rewriting each event continuously. It will make the writer imagines about the characters of the story. The writer certainly used this process because novel needs time to complete, since it has many characters and more conflicts. Thus, it needs lots of ideas that come from the writer's experiences to complete the problems involved in this novel.
Dari yang saya alami, setiap rincian kejadian saya tuliskan, kemudian ada kejadian lagi saya tuliskan kembali, terus menerus saya tuliskan saja dan ternyata cerita tersebut terus berlanjut. Saya menulis hal tersebut karena saya ingin memahami dunia termasuk memahami orang lain.
(Of I experienced, I write each event occurred and there is an event that I 
rewrite more and more until I realize that the story developed continuously. I wrote all those things because I want to understand the world and the other people)

The fourth stage is evaluation process. After writing the all stories, the writer will check by reread the story from the beginning until the end. It was done to make sure if the ideas or parts of the story are valuable or even must be changed.

Setelah selesai menulis baru saya lihat semuanya. Selain itu, biasanya ada proses editing yang akan dilakukan oleh penulis dan juga penerbit.

(After writing all the stories, I will reread them. After that, there is an editing process done by both the writer and the publisher)

The last stage is elaboration, Writer \#2 (PH) developed the story from chapter to chapter in different themes but in related way. Thus, the stories in each chapter change becomes a novel, it is because the writer used elaboration process.

Dari satu tema diperluas menjadi beberapa tema. Temanya beragam, bisa tentang Kisah hidup Kiara, tentang Pelestarian, tentang perlawanan budaya terhadap Amerika. Bahkan tema dalam setiap bab bisa sangat kompleks karena saya tidak membuat sesuatu yang direncanakan jadi saya tuliskan apa yang saya alami. (A theme is elaborated into several themes. The themes are vary ranging from about Kiara lives, about conservation, about cultural resistance to American, even the theme of each chapter can be very complex because I never write anything based on plan, the story will be based on my experience)

From the data above, it was found that in writing a novel, Writer \#2 (PH) used all creative processes. The creative process in writing novel needs high imagination. It is because writing a novel needs time to complete since novel has many characters and the conflict of a novel is more complex. It is the reason why the writer used the all creative processes.

\section{Steps on Creative Process in Writing Poem}

The third writer is female fiction writer (IRZ) from Majalengka. The researcher conducted observation and interview towards Writer \#2. Those processes were held in two times. Writer \#3 (IRZ) can write in any condition because writing is her job, she should send her writing for publication. Thus, the writer has consistency and regulation to write five pages in each day. However, the writer had full time job started from $08.00 \mathrm{am}-08.00 \mathrm{pm}$, but she had to be discipline and had a commitment to write.

After writing a poem, she usually posted her writing in social media, such as blog. She likes writing poems because poem always contains hidden meaning. The meaning of each word in poem was not necessarily had the same meaning with one reader or others. It is because a poem used to express the writer's feeling through writing.

Here, the researcher collected six poems and two short stories of Writer \#3. The poems are Celotehan Hukum, Daun Kering, Dawai di Negeri Pemimpi, Korban Kenangan, My Smiling General, and Tuhan Kenapa. While the short stories are Dunia Tak Pernah Tahu and Terompet Usang.

The researcher finally chose a poem entitled "Dawai di Negeri Pemimpi" to analyze the creative process in writing poem. Table 3 illustrates the creative process in writing poem got from observation towards the selected poem. 
Iin Nuraeni \& Fahrus Zaman Fadhly

Creative Process in Fiction Writing of Three Indonesian Writers

Table 3. List of creative processes in writing poem applied by Writer \#3 (IRZ)

\begin{tabular}{|c|c|c|c|l|}
\hline No & $\begin{array}{c}\text { Steps on the } \\
\text { Creative } \\
\text { Process }\end{array}$ & Yes & No & \multicolumn{1}{|c|}{ Writer' Activities } \\
\hline 1. & Preparation & $\checkmark$ & & Watching news on television \\
\hline 2. & Incubation & $\checkmark$ & & Spontaneity to express feeling in writing. \\
\hline 3. & Insight & $\checkmark$ & & $\begin{array}{l}\text { Has idea of word Sir to represent to } \\
\text { government }\end{array}$ \\
\hline 4. & Evaluation & & $\checkmark$ & \multicolumn{1}{|c|}{} \\
\hline 5. & Elaboration & & $\checkmark$ & \\
\hline
\end{tabular}

The results shown in the table above were gained from document analysis. Whereas, the results from the interview session were showed that Writer \#3 (IRZ) only used three creative processes in writing poem. Those processes are presented below.

The first creative process is preparation. In this first stage, the writer watched news as preparation before writing. Next, the writer did incubation process. In this process, the writer wrote her ideas inspired from watching news and expressed her feeling into simple words in a poem.

Saya mendapat inspirasi dari menonton berita. Kalau untuk Dawai di Negeri Mimpi itu lebih condong pada rasa simpati tentang apa yang terjadi.

(I got the inspiration by watching news. "Dawai di Negeri Mimpi" poem is written triggered by my sympathy toward what is happening.)

Next, the writer used insight process. For instance, the writer was inspired by the use of "Sir" word to represent government.

Terdapat kata Tuan untuk menunjukan pemerintah, terutama bagi anggota DPR, $M P R$, dan Presiden.

(The word "Sir" used in this poem to represent government especially to the members of DPR, MPR and President)

The fourth creative process is evaluation. The writer did not use evaluation process because the writer wrote this poem spontaneously and she only needs 10 minutes to write. Thus, the writer did not use evaluation process.

Proses pembuatannya sekitar 10 menit juga kurang sih. Tidak ada proses mengevaluasi karena itu juga karena sepontan.

(The process of writing this poem only needs about ten minutes. There is no evaluation process because I write it spontaneously)

Besides, the writers did not apply elaboration process because she writes a poem only to express her feeling. Thus, writing a poem rarely needs elaboration process.

Setelah selesai menulis puisi, saya tidak membutuhkan proses elaborasi terhadap puisi tersebut.

(After writing the poem, I did not need elaboration process)

From the data above, it was found that in writing a poem, Writer \#3 used three creative processes. The poem is more sublime and free since it expresses the writer's feeling. Thus, the elaboration process did not need in writing a poem.

\section{Different Ways to Explore Imagination}

There are some ways to explore writers' imagination. Here, the writers explore the imagination with some conceptions such as drawing, a deepen character in the film or story, demands of the text, the reader which was expected by writer, and make a mind mapping. These facts were got from the interview session towards the three fiction writers. 
Writer \#1 (NS) said that one of the ways to explore imagination is by drawing and deepen characters in the film or theater even the fiction writers can make animals character or inanimate objects become life character in their writing. It coincides with theory by Stevenson (2003) who declares that:

The liability to think of something which the subject believes to be real, but which is not real. The ability to think of things as fictional, as opposed to what one believes to be real, or understand of as possibly real.

In contrast, Writer \#2 (PH) had different ways in exploring the imagination process. He observes his daily life to explore his imagination. It coincides also with theory by Stevenson (2003) which suggests that:

The ability to think of (conceive of, or represent) anything at all. The ability to create works of art that express something deep about the meaning of human life, as opposed to the products of mere fantasy.

In contrast, Writer \#3 (IRZ)'s ways in exploring her imagination is by making mind mapping. In creating mind mapping, she writes down some events that continue sequentially. It helps imagination process to create an ending and concept of stories.

From explanations above, it was revealed that fiction writers explore their imagination differently in their writing process. For instance, the writer explores their imagination by drawing and a deepen character of the story. She thinks that drawing cartoon characters can facilitate her thought to imagine what she got by seeing things.

\section{CONCLUSION}

From the results of data analysis, it was revealed that writing short story and novel were almost the same. The difference only comes from the quantity of the text and conflict involved in both texts. Short story is shorter and the novel is longer, the conflict in novel is more complex. Besides, there is only one different creative process between writing novel and short story. Writer \#2 (PH) used elaboration process while writer \#1 (NS) did not.

In contrast, Writer \#3 (IRZ) did not use evaluation and elaboration processes in writing poem. A poem is more sublime and free which is written in simple words that can represent feelings. Thus, the evaluation processes are not needed in writing a poem, and usually a poem cannot be elaborated in other version.

Furthermore, it can be said that the creative process in writing novel had high imagination than short story. The imagination in writing short story was limited because the quantity of the text is shorter and it disrupts the writer's imagination. Besides, writing poem had free imagination and the imagination was not bothered by outline. Thus, there were some different ways of exploring imagination in writing fiction. But, those ways can be classified as follows; drawing and deepen characters in the film or theater, making mind mapping to write, and developing a shorter text.

\section{REFERENCES}

Beaney, M. (2005). Imagination and creativity. London: The Open University.

Csikszentmihalyi, M. (1996). Creativity: Flow and the psychology of discovery and invention. New York, NY: Harper Collins.

Gaut, B. (2010). The philosophy of creativity. Philosophy Compass, 9(6), 1034-1046. doi:10.1111/j.17479991.2010.00351.x.

Gay, L. R., Mills, G. E., \& Airasian, P. W. (2012). Educational research: Competencies for analysis and applications $\left(10^{\text {th }}\right.$ ed.). Boston, MA: Pearson Education, Inc. 
Huy, N. T. (2015). Problems affecting learning writing skill of grade 11 at thong linh high school. Asian Journal of Educational Research, 3(2), 53-69. Retrieved from: http://www.multidisciplinaryjournals. com/wpcontent/uploads/2015/03/P ROBLEMS-AFFECTING-LEARNINGWRITING-SKILL-OF-GRADE-11.pdf.

Kane, T. S. (2000). The oxford essential guide to writing. New York, NY: Oxford University Press, Inc page.

Kaufman, J. C., \& Kaufman, S. B. (2009). The psychology of creative writing. Cambridge: Cambridge University Press.
Morley, D. (2007). The Cambridge introduction to creative writing. Cambridge: Cambridge University Press.

Reisman, F. (2013). Creativity: Concepts, product, process, environment \& technology. New York, NY: KIE Conference Book Series.

Pope, R. (2005). Creativity: Theory, history, practice. New York, NY: Routledge.

Wallas, G. (1926). Art of thought. New York, NY: Harcout Brace \& Co.

Weldon, F. (2013). Fay Weldon speaks up for creative writing. United Kingdom: The Times Higher Education. 